\title{
25. Poverty and the family in Europe
}

\author{
Jonathan Bradshaw and Rense Nieuwenhuis
}

\section{INTRODUCTION}

Poverty has a severe impact on families, and particularly on children who grow up in poor families. This is undeniably the case even in rich societies. Compared with higher-income families, poor families are less able to financially invest in their children, which is known to impair children's cognitive development and social relations; and they experience more stress, which has been linked to parenting styles that are less sensitive to the needs of children (Van Lancker and Vinck 2019). Income poverty and material deprivation explain a large share of the differences between children who grow up in single-parent and two-parent families, with the former group having lower levels of emotional well-being (Treanor 2018) and school performance (De Lange and Dronkers 2018).

The objective of this chapter is to explore family poverty and how it is mitigated by social policy in European countries. It examines the poverty risks of families in Europe, with an emphasis on families with dependent children, as these families tend to be at greater risk of poverty than others because they have more members to maintain with a given income. Single people and childless couples mainly have themselves to support financially, although single adults have increasingly been recognised as a group who are at risk of poverty as well. The risk of poverty for multi-family households can also be high, especially if they include dependent children and retired relatives. However, in such arrangements, income from pensions and earnings may contribute to the households' living standards (Verbist et al. 2020). The risk of poverty is elevated if there is only one parent in the household, which is an increasingly common family type in European countries (Chzhen and Bradshaw 2012; Nieuwenhuis and Maldonado 2018a); or if only one parent in a couple is an earner, usually because the other parent is caring for children.

In light of these poverty risks, European societies have developed social policies to help families with children combine work and childrearing. To examine whether and, if so, how these policies are effective, the following sections of this chapter outline the principles that underlie the various definitions of 'poverty' commonly used in the European Union (EU), present the three main types of theories of what causes poverty, and describe a number of anti-poverty policies that have been implemented in Europe. In the discussion on policies, a distinction is made between 'active' and 'passive' social policy approaches. One of the 'active' objectives of providing childcare or childcare subsidies, maternity benefits, and parental leave arrangements is to encourage and enable parents to be earners. Parents who do not participate in the labour market because they are unemployed, sick, or disabled may be covered by passive social protection (social insurance or social assistance) schemes. To help parents manage the extra costs associated with raising children, all European countries have developed child benefit packages that include transfers to parents who have children, regardless of whether they are employed (Bradshaw 2018; Van Mechelen and Bradshaw 2013). 


\section{FAMILY POVERTY}

\subsection{Measures}

There is no single, perfect measure of family poverty. Broadly defined, poverty can be understood as lacking the resources considered necessary to maintain an adequate standard of living, or to participate in society (e.g., Smeeding 2017). This general concept can be operationalised in myriad ways that highlight different aspects of poverty, and that complement each other.

When designing a measure of poverty, the analyst has to make a number of decisions. While this list is not intended to be exhaustive, we outline here seven important decisions that an analyst would typically have to make in operationalising such a measure. In the next section, we present in more detail three of the most important definitions that are used in the EU.

First, poverty of what needs to be defined. Poverty can, for instance, be measured based on income before or after taxes, benefits, wealth or savings, expenditures, deprivation of capabilities, or inability to participate in society (Cowell 2011; Sen 1993).

Second, the reference period during which the resource is measured needs to be defined. For example, when measuring income poverty, annual income is typically considered, as this metric is in line with income tax reference periods. However, such a poverty measure would not pick up on problems related to short-term income losses or seasonal fluctuations in income.

Third, the unit of analysis needs to be selected. If, for instance, income poverty is being measured, the analyst must decide whether the income being considered is that of individuals, of all of the household members combined, or, in the case of multi-family households, of separate families. In households, incomes are typically equivalised for household size to account for differences in need and economies of scale (Atkinson et al. 1995; Daley et al. 2020).

Next, assumptions must be made about how resources are shared within the unit. When the unit of analysis is the individual, it is typically assumed that there is no sharing of resources; whereas when the unit of analysis is the household, it is typically assumed that the household's resources are shared. When analysing income poverty, differences in need between households as well as economies of scale are accounted for by dividing the household income by the equivalent number of household members. It is also possible to assume that there is a partial sharing of resources. If it is assumed that there is a full sharing of resources, all household/ family members are considered to have the same poverty status, even though it has been documented that not all household members have equal access to and control over household resources, with women often being at a disadvantage (Bennett 2013). A rarely recognised consequence of the assumption that there is an equal sharing of resources is that men and women living in the same household are assigned the same poverty status. When that is the case, researchers may not be able to observe gender gaps in poverty driven by gender inequality within heterosexual couples, but only those driven by gender differences in poverty among single-adult households (Doctrinal and Nieuwenhuis 2019).

Fifth, the poverty line, or the threshold below which people are considered to be poor, needs to be defined. This line can be set in absolute terms, or in relative terms (e.g., an income below a certain percentage of median income in a country at a specific year). An absolute poverty line is often based on the value of the goods that are considered necessary for a minimum standard of living. An 'absolute' poverty line is set and kept constant across contexts (except for corrections for inflation). However, even an 'absolute' poverty line is inherently relative in the sense that what is considered necessary for a minimum standard of living is determined in relation to 
how other people live (Townsend 2010). A relative poverty line, by contrast, is continuously updated across contexts and over time, and is relative to the incomes (or other resources) of others in the same society. Absolute and relative poverty lines can also be combined. For instance, in the 'weakly relative' poverty line that is used for measuring poverty around the world (Atkinson 2019), the relative poverty line is set at 50 per cent of median income, with an absolute minimum of $\$ 1.90$ (in international dollars).

Sixth, the analyst must decide how to calibrate the poverty measure by selecting which weights to apply to those below the poverty line (Amiel and Cowell 1999). The headcount poverty rate counts all individuals below the poverty line equally. An alternative approach that picks up on differences in poverty intensity is to weight individuals based on their distance from the poverty line, which results in a measure called the poverty gap.

Finally, distinctions can be made between unidimensional and multidimensional poverty indicators. An example of the former is income poverty, which is based on just one resource; whereas an example of the latter is the global multidimensional poverty index, which combines 10 indicators in the areas of health, education, and standard of living (Alkire et al. 2015).

\subsection{Poverty Measures in a European Perspective}

In the EU (and in other European countries), a number of conventions have been established that we will discuss here in more detail. The at risk of poverty or social exclusion (AROPE) indicator was the headline indicator for the EU 2020 Strategy target of lifting at least 20 million people out of the risk of poverty or social exclusion between 2008 and 2020. The indicator is used to monitor progress towards the United Nations Sustainable Development Goal 1, and is currently a main indicator in the Social Scoreboard for the European Pillar of Social Rights. An individual is considered at risk of poverty or social exclusion if $\mathrm{s} / \mathrm{he}$ is either at risk of poverty, severely materially deprived, or living in a household with a very low work intensity. These three constituting indicators are also used as separate indicators of living conditions and poverty.

A person is considered at risk of poverty (AROP) if s/he is living in a household with an equivalised, disposable annual household income below 60 per cent of the national median household income. Within the framework of the discussion above, the AROP is a unidimensional measure of relative income poverty, as the poverty line is set at different levels in each country, and varies over time as median household incomes increase or decrease. While there are a number of problems associated with using this measure (for a discussion, see Bradshaw and Movshuk 2019), it can provide some insights into country differences in poverty risks. Individuals are considered severely materially deprived if they cannot afford four or more of the following items: to pay their rent, mortgage, or utility bills; to keep their home adequately warm; to handle unexpected expenses; to eat meat or protein regularly; to go on holiday; to own a television set; to own a washing machine; to own a car; or to have a telephone. As severe material deprivation is an absolute, multidimensional measure, the same criteria are used throughout the EU. Guio et al. (2017) have proposed an alternative material and social deprivation indicator based on 13 items that are selected using a systematic item-by-item robustness analysis (available only after 2014). Finally, a person is considered to live in a household with low work intensity if the working-age household members (ages 18-59, excluding students under age 24) worked less than 20 per cent of their total potential during the previous 12 months. This is a unidimensional, absolute measure of social exclusion. 


\subsection{Poverty Rates in European Perspective}

Figure 25.1 presents the trends in AROPE, and the three constituting indicators, in the EU 27 countries from 2005 to 2018 . The results for the EU show a clear decline (albeit with a temporary increase around 2012) in AROPE, as well as in indicators of severe material deprivation and living in a household with low work intensity. The results also show, however, that AROP remained stable, or even increased slightly. These findings are perhaps particularly enigmatic given the decline in the numbers of people living in a household with very low work intensity.

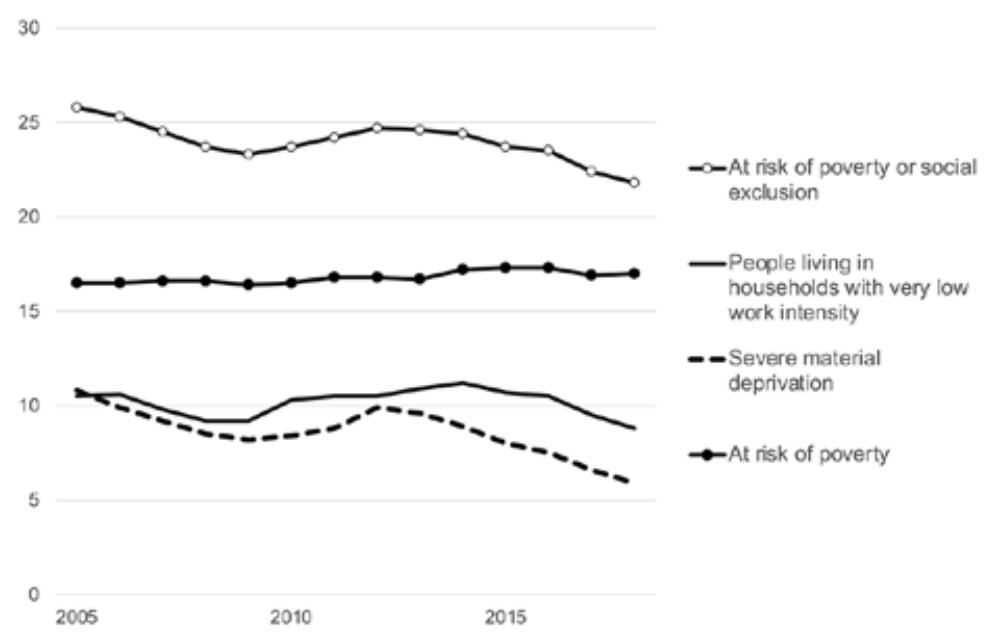

Source: Eurostat (2020).

Figure 25.1 European Pillar of Social Rights indicators of people at risk of poverty or social exclusion, 2005-18, EU-27

To further examine the development in AROP, we turn to the country-specific trends in the AROP rate. We focus only on AROP, and not on severe deprivation and work intensity, because AROP had the highest shares of the three constituting indicators, and was the only indicator that was not declining. Figure 25.2 shows that between 2005 and 2018, there were fairly substantial declines (of about five percentage points or more) in AROP in Poland and Ireland, and smaller declines in a number of other countries. However, over the same period, and consistent with the overall trend displayed in Figure 25.1, AROP increased in 18 out of the 31 countries, with Luxembourg and Sweden having particularly large increases. Note, for example, that Sweden had the lowest AROP in 2005 at 9.5 per cent; whereas in 2018, Sweden occupied a middle position, at 16.4 per cent. Thus, Sweden had the largest increase in AROP among the countries studied. Elsewhere, it has been shown that Sweden has recorded the largest increase in economic inequality since the 1980s among the Organisation for Economic Co-operation and Development (OECD) countries (OECD 2015), and that the rise in poverty in Sweden has been concentrated among single parents and single adults without children (Alm et al. 2020). 


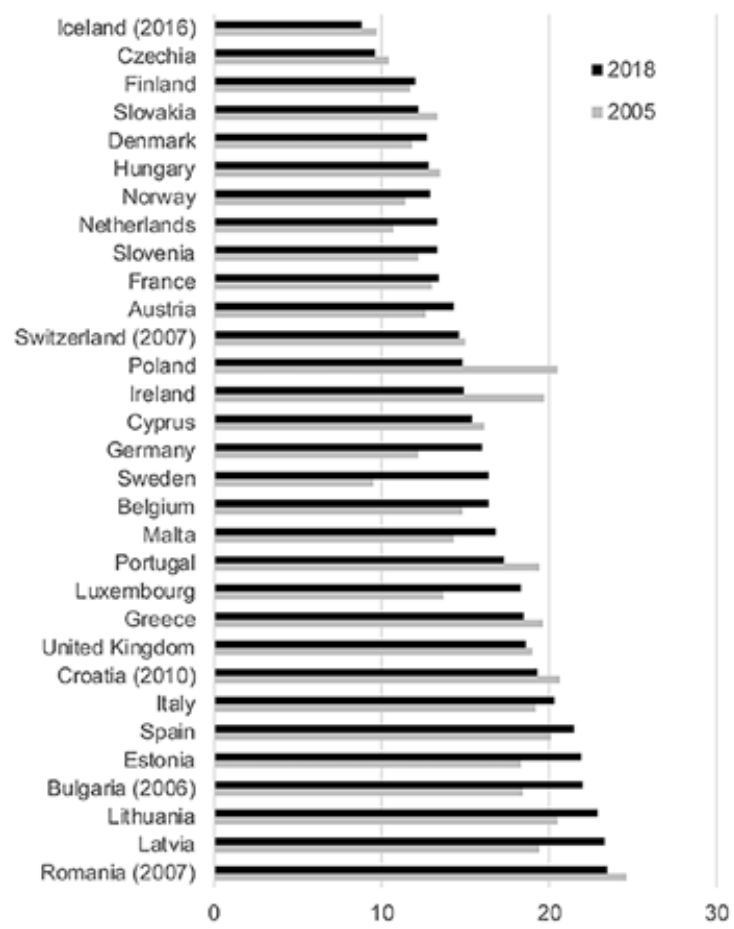

Source: Eurostat (2020).

Figure 25.2 At risk of poverty in 2005 and 2018, in European countries

\section{INDIVIDUAL DETERMINANTS OF POVERTY}

Theories on the causes of poverty can broadly be categorised as focusing on behavioural, structural, and political factors (Brady 2009; for a similar classification, see Sumner 2016). Behavioural theories are inherently individualistic, and explain poverty by the choices people allegedly make, such as being a single mother or unemployed. Structural theories hold that economic and demographic contexts affect people's behaviour, directly affect poverty, and alter the poverty risks associated with certain behaviours. Political theories explain poverty as resulting from power relations shaping political institutions that (re)distribute resources.

A number of determinants relevant to the poverty of the family follow from these theories. The individual-level determinants we focus on are aspects of family formation and aspects of employment. Two aspects of family formation are particularly relevant to the focus of this handbook. It has already been mentioned that families with children have a greater likelihood of living in poverty, because they need a higher income to have a standard of living similar to that of families without children, and because mothers with dependent children are less likely to be employed (Nieuwenhuis et al. 2012). Indeed, across European countries, it is the case that the more children a family has, the greater their poverty risk (Berthoud and Iacovou 2006; Bradshaw et al. 2006; Lohmann and Crettaz 2018). The second aspect of family formation that is often linked to poverty is single parenthood, most commonly single motherhood. In 
the context of the United States, McLanahan's (2004) diverging destinies theory argues that lower-educated mothers have been increasingly overrepresented among single mothers, and that, for this reason, being a single mother has increasingly been associated with having children at a young age, not being employed, and having a low family income. This (mostly) behavioural explanation has intuitive appeal: if having a low level of education is a well-documented determinant of poverty, and having a low level of education is more common among single than married mothers, it may be assumed that this characteristic of single mothers contributes to their poverty. There are, however, a number of limitations to this individualistic explanation of poverty among single parents. First, research has shown that upon closer examination, the educational gradient in single motherhood plays only a small role in their elevated poverty risks (Härkönen 2018; for a similar analysis, see Bernardi and Boertien 2017). Second, this explanation does not (explicitly) account for structural factors that make having a low level of education a much greater risk factor for poverty in some contexts than others, or that mean that being employed does not protect against poverty to the same extent in some contexts as in others (Alm et al. 2020; Brady et al. 2017; Härkönen et al. 2016). Finally, power relations and the political context - ranging from patriarchal institutions (Cooke 2018) to inadequate levels of redistribution (Cantillon et al. 2017, 2018) - are not accounted for. Based on analyses such as these, Nieuwenhuis and Maldonado (2018a) have argued that poverty among single parents can be explained by single parents facing a triple bind: in addition to being more likely to have inadequate resources, such as a low level of education, single parents also frequently have inadequate employment, and are exposed to 'inadequate social policy'.

Employment rates among single parents are high (Nieuwenhuis and Maldonado 2018a). Indeed, a recent study found that women living with dependent children and a partner are more likely to reduce their employment than women living with a partner and no children or single mothers (Muller et al. 2020). These findings challenge behavioural explanations based on the supposed joblessness of single parents. However, a structural account of (un)employment as a determinant of poverty has pointed to the impact of a rise of precarious employment (Kalleberg 2018), such as working on temporary contracts, having limited employment protections, being forced to work part time or with irregular hours, or having to rely on seasonal work. The distribution of wages has become more dispersed, with wage growth being more limited in the lower deciles, and substantial wage growth in the higher deciles (Bernstein 2016; Björklund and Jäntti 2012). As a result, having a job is not a guarantee against being at risk of poverty. This is acknowledged in the concept of in-work poverty, that refers to people being at risk of poverty despite having a job (Lohmann and Marx 2018).

Naturally, family form and employment clearly intersect as determinants of poverty, which suggests that behavioural and structural theories of poverty are interrelated. There is, for example, evidence that compared with two-parent families, single parents have worse worklife balance and lower job security (Esser and Olsen 2018), and face a much greater risk of poverty even if they have a job, in large part because there is only one earner in the household (Nieuwenhuis and Maldonado 2018b). It has also been shown that the number of earners in different household types has wider implications. This finding is best illustrated by looking at the rapid rise in poverty observed in Sweden (see Figure 25.2). According to recent research, this trend was attributable in part to reduced access to and reduced levels of unemployment insurance benefits, but the level of social protection only mattered for those families who did not have an additional earner in the household (Alm et al. 2020). In other words, households or families who could compensate for a loss of income due to unemployment because there 
was a second earner in the household typically managed to avoid poverty risks. However, for families who relied on a single earner, the single earner becoming unemployed was associated with a very high risk of poverty. It is worth noting that this association was found for not just for single parents, but for single adults without children. Thus, these family types had very similar poverty trends. These findings have implications beyond Sweden, and suggest that especially in dual-earner societies, single adults without children should be considered a new social risk group for poverty. In addition, these findings indicate that the poverty risks of single parents are related not just to having children or being single per se, but to the poverty risks associated with having only a single income from employment in an increasingly precarious labour market.

\section{POLICY AND POVERTY}

Although identifying the individualistic determinants of poverty is important for understanding the underlying mechanisms of poverty, in analyses of cross-country differences in poverty rates, behavioural factors tend to be outperformed by structural and political determinants. Thus, this cross-national variation in poverty rates is better explained by structural factors, such as the abovementioned employment conditions; and by political determinants, such as levels of redistribution by the welfare state (Brady 2009; Brady et al. 2017).

\subsection{Active Social Policy}

Social policy in European countries is increasingly focused on promoting employment to combat poverty. In the context of the EU, this link is made explicit in the targets, strategies, and directives adopted by the European Commission. However, this development can be observed in many other countries as well. In the social investment paradigm of the welfare state, the emphasis has shifted away from providing families with social protection in the form of income transfers to 'repair' financial adversity, and towards investing in people's skills and employability to 'prepare' them for financial independence in the market economy (Morel et al. 2012). As has been documented in more detail by Neyer in this volume, this is typically done through active social policies, such as employment assistance, direct job creation, and skills training (rather than through social security unemployment benefits); and through the promotion of higher education, parental leave (including for fathers), and early childhood education and care (Bonoli 2013; Hemerijck 2017; Morel et al. 2012).

From a family perspective, it is relevant that these active social policies were introduced in part as a response to changing family relations. As female labour force participation rose and women were better represented in parliaments, countries expanded their expenditures on early childhood education and care (Bonoli and Reber 2010). In recent decades, European policy-makers came to believe that post-war welfare state policies that primarily focused on protecting income were ill-equipped for dealing with so-called 'new social risks', including the challenges of reconciling work and family life, single parenthood, the lack of career continuity, precarious employment, and low or obsolete skills (Bonoli 2013; Morel et al. 2012). Nonetheless, these European social policy developments were criticised for perpetuating familism (Daly 2011), and for obscuring and taking for granted the gender inequality in care responsibilities within the household (Saraceno 2015). 
From a policy perspective, it is relevant to go back to the trends presented in Figure 25.1. The figure shows that while substantial efforts were made to promote employment, and the share of people living in households with a very low work intensity indeed declined, the trend in relative income poverty (AROP) stayed constant, or even marginally increased. These trends in poverty in Europe have been described as 'disappointing' (Jenkins 2020; Vandenbroucke and Vleminckx 2011). Focusing on single mothers, Jaehrling et al. (2015) found that while the introduction of the active social policy approach did increase their employment rates, it failed to reduce their poverty. In a study of the long-term trends in women's employment, Nieuwenhuis et al. (2020) found that even though the households in which women are working are less likely to be at risk of poverty, the marked rise in female labour force participation that has been observed in many European (and OECD) countries in recent decades has done little to reduce poverty levels. The authors hypothesised that this is because much of the growth in women's employment has been either in households who have failed to escape poverty (in-work poverty), or in households who were not poor to begin with.

As the benefits of employment can far exceed the a pay checque, active social policies can have important benefits for workers and families. It has been shown that labour market policy initiatives, such as training programmes, employment subsidies, and direct job creation, are associated with greater transitions out of inactivity and unemployment, and into employment (Fredriksson 2020). There is also evidence that having access to parental leave is associated with reduced poverty among single parents, provided it is paid well (Maldonado and Nieuwenhuis 2015); and that early childhood education and care not only facilitates the inclusion of mothers in the labour market (Pettit and Hook 2009), as it also provides more equal opportunities for children (Gambaro et al. 2015). However, for a number of reasons, employment growth does not guarantee reductions in poverty. Active social policy in the form of public services has a tendency to benefit work-rich households (Cantillon 2011; Ghysels and Van Lancker 2011; Vandenbroucke and Vleminckx 2011). This is because the focus of policy-makers is generally on economic growth rather than social inclusion (Atkinson 2010), and the support for employment through in-work credits often comes at the expense of minimum income protection for those out of work (Cantillon et. al. 2019).

When we take the evidence presented above together (see also Neyer in this volume), we see that active social policies clearly play an important role. But since these policies clearly are not a panacea for poverty, passive social policies in the form of redistribution will continue to be needed.

\subsection{Passive Social Policy}

To examine the impact of redistribution and income transfers (passive social policy), we focus on the extent to which these policies have been effective in reducing poverty among children and their families. We have chosen to investigate this issue for a number of reasons: first, large families with children are at greater risk of poverty; second, growing up in poverty has severe consequences later in life; and, third, by focusing on children, we can capture a larger set of redistributive policies. We cast a wide net to capture a range of policies that are relevant to the poverty risks of children (and their families), while focusing on policies specifically tailored to children, such as family benefits and child tax credits; and on policies that are aimed at a wider population of families, but that are still of potential relevance to children, such as housing benefits or social assistance. 
Every country has a system of transfers designed to help families manage the costs of childrearing. How effective are these systems at reducing child poverty? This question is explored in Figure 25.3, which shows what the under age 18 AROP indicator would have been if we had excluded all transfers from net income, and what the share was for the same year after including transfers. The bars are ordered by the level of AROP after transfers. We can see that the countries that have low poverty before transfers also tend to have low poverty after transfers, which indicates market income inequality plays an important role in shaping countries' child poverty rates. However, given that there is substantial variation around this pattern, it appears that some welfare states achieve more poverty reduction through redistribution than others. We can, for example, see that Hungary has the most effective transfers, as the country starts with the second-highest (after the United Kingdom) pre-transfer poverty rate, but reduces it by 27 percentage points. We can also observe that Spain, by contrast, starts with a comparatively high child poverty rate before transfers, but reduces it by only six percentage points. In addition, it is apparent that the Nordic countries, Poland, Ireland, and Slovenia have more effective transfers; while the southern European countries, together with Bulgaria and Romania, have less effective transfers.

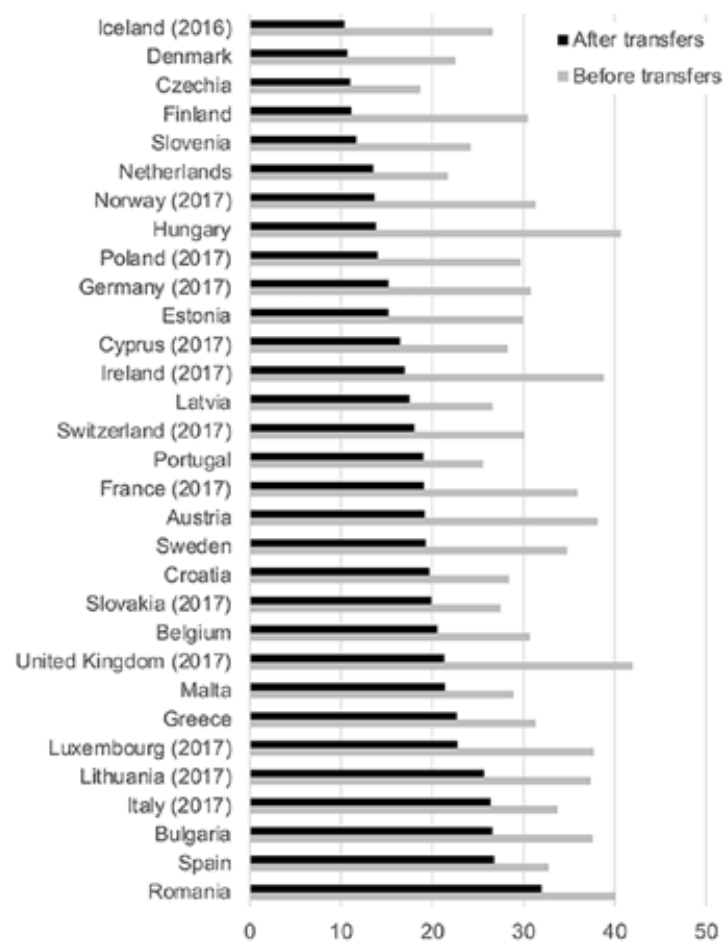

Note: Pre- and post-transfers. Reporting year 2018 unless stated.

Source: Eurostat (2020).

Figure 25.3 At risk of poverty indicator for children under age 18 
Table 25.1 Structure of the child benefit package for working families with children

\begin{tabular}{|c|c|c|c|c|c|c|}
\hline & $\begin{array}{c}\text { Social } \\
\text { assistance }\end{array}$ & $\begin{array}{c}\text { Housing } \\
\text { benefit }\end{array}$ & $\begin{array}{c}\text { Universal family } \\
\text { benefit }\end{array}$ & $\begin{array}{c}\text { Means-tested } \\
\text { family benefit }^{1}\end{array}$ & $\begin{array}{c}\text { In-work } \\
\text { benefit }\end{array}$ & $\begin{array}{c}\text { Child tax } \\
\text { benefit }^{2} \\
\end{array}$ \\
\hline Austria & & $\mathrm{X}$ & & $\mathrm{X}$ & & $\mathrm{X}$ \\
\hline Belgium & & & & $\mathrm{X}$ & & $\mathrm{X}$ \\
\hline Bulgaria & & & $\mathrm{X}$ & & & $\mathrm{X}$ \\
\hline Cyprus & $\mathrm{X}$ & $\mathrm{X}$ & $\mathrm{X}$ & & & \\
\hline Czech Republic & & $\mathrm{X}$ & $\mathrm{X}$ & & & $\mathrm{X}$ \\
\hline Denmark & $\mathrm{X}$ & $\mathrm{X}$ & & $\mathrm{X}$ & & $\mathrm{X}$ \\
\hline Estonia & & & $\mathrm{X}$ & & & $\mathrm{X}$ \\
\hline Finland & $\mathrm{X}$ & $\mathrm{X}$ & $\mathrm{X}$ & & $\mathrm{X}$ & \\
\hline France & & $\mathrm{X}$ & $\mathrm{X}$ & $\mathrm{X}$ & $\mathrm{X}$ & $\mathrm{X}$ \\
\hline Greece & & & & $\mathrm{X}$ & & $\mathrm{X}$ \\
\hline Germany & & $\mathrm{X}$ & & $\mathrm{X}$ & & $\mathrm{X}$ \\
\hline Croatia & & & & $\mathrm{X}$ & & $\mathrm{X}$ \\
\hline Hungary $^{2}$ & & & $\mathrm{X}$ & & & $\mathrm{X}$ \\
\hline Iceland & & $\mathrm{X}$ & & $\mathrm{X}$ & & 3 \\
\hline Ireland & & $\mathrm{X}$ & $\mathrm{X}$ & & $\mathrm{X}$ & $\mathrm{X}$ \\
\hline Italy & & & & $\mathrm{X}$ & & $\mathrm{X}$ \\
\hline Lithuania & $\mathrm{X}$ & & $\mathrm{X}$ & $\mathrm{X}$ & & \\
\hline Latvia & & $\mathrm{X}$ & & & & $\mathrm{X}$ \\
\hline Luxembourg & $\mathrm{X}$ & $\mathrm{X}$ & $\mathrm{X}$ & & & $\mathrm{X}$ \\
\hline Malta & & $\mathrm{X}$ & $\mathrm{X}$ & $\mathrm{X}$ & $\mathrm{X}$ & $\mathrm{X}$ \\
\hline Netherlands & & $\mathrm{X}$ & $\mathrm{X}$ & $\mathrm{X}$ & & $\mathrm{X}$ \\
\hline Norway & & $\mathrm{X}$ & $\mathrm{X}$ & & & $\mathrm{X}$ \\
\hline Poland & & $\mathrm{X}$ & $\mathrm{X}$ & $\mathrm{X}$ & & $\mathrm{X}$ \\
\hline Portugal & & & & $\mathrm{X}$ & & $\mathrm{X}$ \\
\hline Romania & & & $\mathrm{X}$ & $\mathrm{X}$ & & $\mathrm{X}$ \\
\hline Slovenia & $\mathrm{X}$ & $\mathrm{X}$ & & $\mathrm{X}$ & & $\mathrm{X}$ \\
\hline Slovakia & & & $\mathrm{X}$ & & $\mathrm{X}$ & \\
\hline Spain & & & & $\mathrm{X}$ & & $\mathrm{X}$ \\
\hline Sweden & & $\mathrm{X}$ & $\mathrm{X}$ & & & \\
\hline Switzerland & & & $\mathrm{X}$ & & & $\mathrm{X}$ \\
\hline United Kingdom & & $\mathrm{X}$ & & $\mathrm{X}^{4}$ & & \\
\hline
\end{tabular}

Note: ${ }^{1}$ OECD does not differentiate between means-tested and non means-tested family benefits, but they can be identified by observing whether the amount does or does not vary with earnings. ${ }^{2}$ Identified by observing whether families with children pay more or less income tax or social security contributions than families without children on the same earnings. In Germany, the Netherlands, and Switzerland families with children also pay lower social security contributions. ${ }^{3}$ Families with children in Iceland pay more tax because family benefits are taxable. ${ }^{4}$ The child benefit was universal, but families with a parent earning over $£ 50,000$ per year are no longer eligible to receive it.

Source: Own calculations using output from the OECD tax-benefit web calculator.

Among the questions that arise when considering these results are which types of redistributive policies are the national tax benefit systems comprised of, and which of these systems are more effective than others. Our analysis attempts to answer these questions using the OECD 
tax/benefit data. This approach enables us to compare across countries how tax and benefit systems assist 'model families'. The methodology of 'model families' is often used in comparative welfare state research (Nelson et al. 2020), and entails calculating the social rights that a well-defined model or ideal typical family will receive in different countries or time periods. Because the family is kept constant, differences can only be attributed to how each country's welfare state is set up, rather than to differences in the social backgrounds or compositions of families across countries.

Table 25.1 first lists countries according to which elements their benefit packages for working families with children include. This list effectively shows which policies make it more likely that a couple with two children and an employed parent will have a higher income than a childless couple with the same earnings (the 'child benefit package'). For all of these elements except universal family benefits, the extra amount parents receive will depend on their earnings. If they receive housing benefits, they will pay less rent; and if they receive the child tax benefit, they may pay less tax or receive a tax rebate that is higher than that of a childless couple. The in-work benefit is a somewhat anomalous classification by OECD. For example, in Ireland, the family income supplement might have been better classified as a means-tested family benefit.

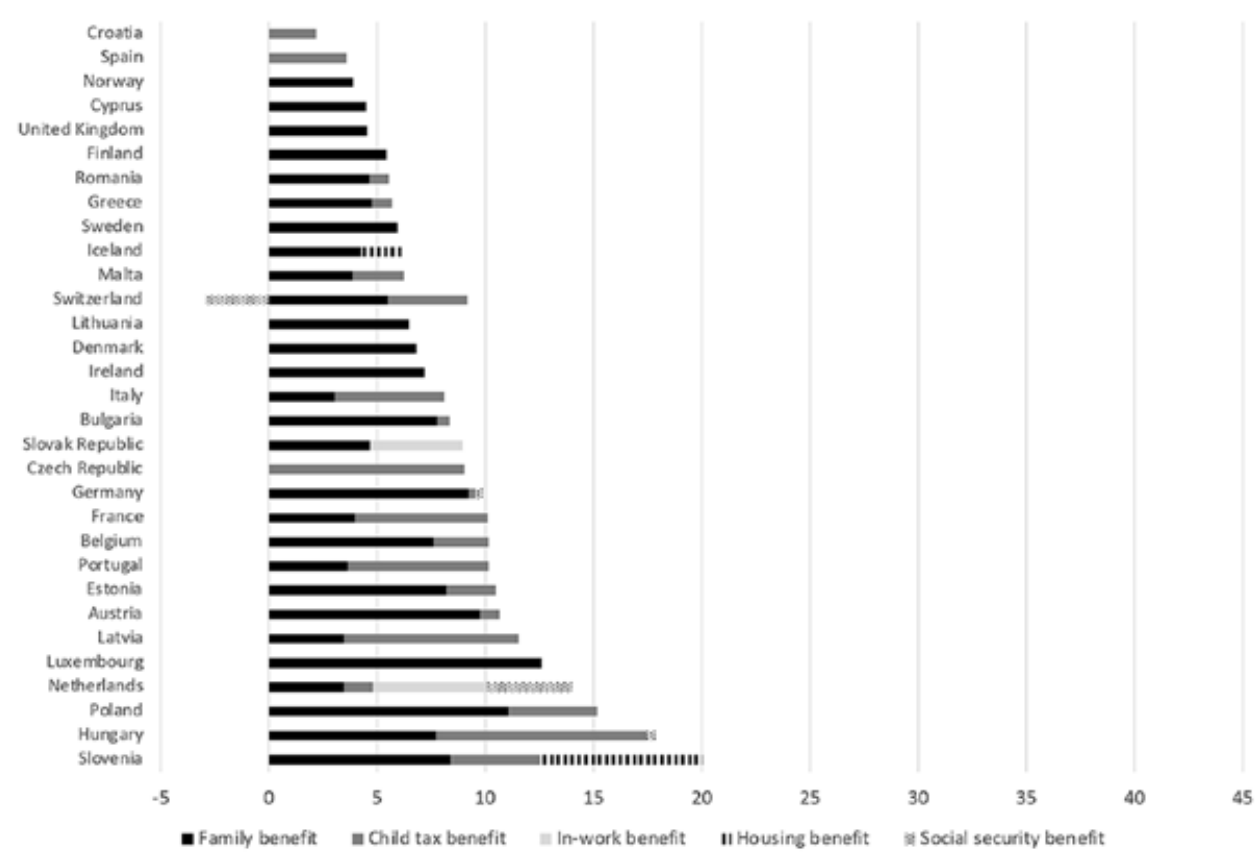

Note: Couple plus two children, both adults employed for 65 per cent of the average wage. Reporting year 2018. Source: Own calculations using output from the OECD tax-benefit web calculator (OECD 2019).

Figure 25.4 Child benefit package as percentage of average earnings

Six countries may provide some social assistance to low-paid working families. Seventeen countries help offset the cost of rent by providing families with housing benefits that are more 
generous if children are present. In addition, 19 countries have universal child benefits, 18 countries have means-tested child benefits, and six countries have both. Five countries have in-work benefits, and 24 countries offer some kind of tax benefit. All countries provide more than one type of benefit, with Denmark, Finland, Luxembourg, Malta, the Netherlands, and Poland offering four types each.

Next, we assess the level of each child benefit package by comparing the cash benefits/ tax benefits families with children receive with those received by otherwise identical families without children. We focus on families in which the adults are working. First, in Figure 25.4, we show the child benefit package for a couple with two children in which both adults are employed and earn 65 per cent of the average wage. For this family type, Hungary and Slovenia have the most generous packages; and Croatia, Spain, Norway, and Cyprus have the least generous packages. It is difficult to discern any association between the level and the structure. It is possible that those countries that have more than one element in their packages also tend to have more generous benefits. This is, for example, the case in Hungary, the Netherlands, and Slovenia. In Switzerland, the couple with children is presumably paying social security contributions on their family benefits.

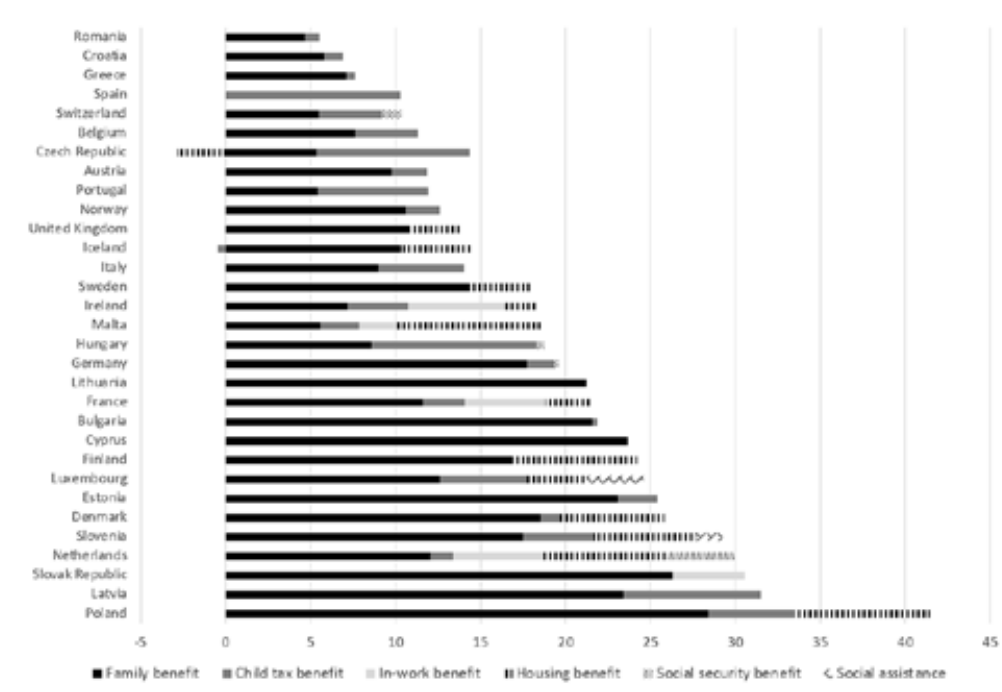

Note: Single parent plus two children, earning 65 per cent average wage 2018.

Source: Own calculations using output from the OECD tax-benefit web calculator (OECD 2019).

Figure 25.5 Child benefit package as percentage of average earnings

A different picture emerges in Figure 25.5, which focuses on a single parent with two children earning 65 per cent of the average wage. For this family type, Poland, Latvia, the Slovak Republic, the Netherlands, and Slovenia have the most extensive child benefit packages; while Romania, Croatia, and Greece have the least generous packages. Once again, there is no clear pattern between the structure and the level, other than that the countries with more than one element in their packages tend to have more generous packages. This is, for example, the case for Poland, the Netherlands, and Slovenia. In the Czech Republic, the single parent with 


\section{Research handbook on the sociology of the family}

children receives less generous housing benefits than the single person, possibly because his/ her family benefits are treated as income in the means test.

Focusing on working families with children allowed us to highlight that even households with working adults receive a considerable amount of their total disposable household income from cash benefits and tax benefits. Single parents tend to receive more benefits, which is largely because a smaller share of their household income comes from earnings. In the comparison between Figures 25.4 and 25.5, which are based on otherwise identical model household types, we can see that this is not because single parents work or earn less, but simply because there is only a single earner in their household.

\section{CONCLUSION}

Poverty has severe consequences for families, and children can experience long-lasting negative effects from growing up poor. Thus, it is not surprising that European countries (and beyond) attempt to reduce their poverty levels. While such efforts are increasingly in the form of active social policies, as this chapter has demonstrated, passive social policies based on income transfers and redistribution - including for people in employment - remain important.

This chapter provided a detailed description of commonly used measures of poverty, and of the dimensions in which they differ. Behavioural, structural, and political explanations for poverty were outlined. We argued that in explanations of cross-national differences in poverty, individual-level determinants of poverty (such as low education, single parenthood, or the number of earners in the household) are outperformed by contextual determinants (such as policies). These findings underline the relative importance of structural and political theories of poverty.

Although many European governments have engaged in efforts to promote employment, and women's employment has indeed risen in many European countries in recent decades, relative income poverty in Europe has not been declining. The continued prevalence of in-work poverty suggests that employment growth is not a panacea for poverty. The chapter outlined the sometimes complex child benefit packages that European countries provide to families with children. Such redistributive efforts by the state are often successful in reducing the risk of poverty, and, thus, in mitigating its impact. Without these social policies, poverty generated by the market would be much higher than is currently the case in most countries. But it is also true that in many EU countries, the efforts being made by the state are not enough.

Child poverty rates have increased in half of the EU countries since the global recession, and they have risen more than the poverty rates among pensioners (Bradshaw and Chzhen 2015). There is evidence from many countries that this is because of cuts in child benefit packages (Cantillon et al. 2017). Some EU countries are reducing their family benefits and allowing their child poverty rates to rise at a time when most non-EU countries are recognising the importance of social protection in tackling global poverty. 


\section{ACKNOWLEDGEMENTS}

We thank Anne-Catherine Guio, University of Luxembourg, for contributing to some of the analyses. Nieuwenhuis was financially supported by FORTE: The Swedish Research Council for Health, Working Life and Welfare (grant number 2018-00988).

\section{REFERENCES}

Alkire, S., J.M. Roche, S. Seth, and A. Sumner (2015), 'Identifying the poorest people and groups: Strategies using the global multidimensional poverty index: Identifying the poorest people and groups', Journal of International Development, 27 (3), 362-87. doi:10.1002/jid.3083.

Alm, S., K. Nelson, and R. Nieuwenhuis (2020), 'The diminishing power of one? Welfares state retrenchment and rising poverty of single-adult households in Sweden 1988-2011', European Sociological Review, 36 (2), 198-217. doi:10.1093/esr/jcz053.

Amiel, Y. and F.A. Cowell (1999), Thinking about Inequality: Personal Judgment and Income Distributions, Cambridge: Cambridge University Press.

Atkinson A.B. (2010), 'Poverty and the EU: The new decade' (Macerata Lecture on European Economic Policy), Working Paper 24, Università degli Studi di Macerata, Dipartimento di Studi sullo Sviluppo Economico, Macerata.

Atkinson, A.B. (2019), Measuring Poverty around the World, Princeton, NJ: Princeton University Press.

Atkinson, A.B., L. Rainwater, and T.M. Smeeding (1995), Income Distribution in OECD Countries: The Evidence from the Luxembourg Income Study, Paris: OECD.

Bennett, F. (2013), 'Researching within-household distribution: Overview, developments, debates, and methodological challenges', Journal of Marriage and Family, 75 (3), 582-97. doi:10.1111/jomf .12020 .

Bernardi, F. and D. Boertien (2017), 'Non-intact families and diverging educational destinies: A decomposition analysis for Germany, Italy, the United Kingdom and the United States', Social Science Research, 63, 181-91. doi:10.1016/j.ssresearch.2016.09.004.

Bernstein, J. (2016), 'Wages in the United States: Trends, explanations, and solutions', in I. Kirsch and H. Braun (eds), The Dynamics of Opportunity in America, Cham: Springer International, pp. 167-95. doi:10.1007/978-3-319-25991-8 6.

Berthoud, R. and M. Iacovou (2006), 'The economic position of large families', DWP Research Report, London: DWP.

Björklund, A. and M. Jäntti (2012), 'Country case study: Sweden', in S.P. Jenkins, A. Brandolini, J. Micklewright, and B. Nolan (eds), The Great Recession and the Distribution of Household Income, Oxford: Oxford University Press, pp. 153-75. doi:10.1093/acprof:oso/9780199671021.003.0006.

Bonoli, G. (2013), The Origins of Active Social Policy: Labour Market and Childcare Polices in a Comparative Perspective, 1st edition, Oxford: Oxford University Press.

Bonoli, G. and F. Reber (2010), 'The political economy of childcare in OECD countries: Explaining cross-national variation in spending and coverage rates', European Journal of Political Research, 49 (1), 97-118. doi:10.1111/j.1475-6765.2009.01884.x.

Bradshaw, J. (2018), 'Family benefit systems', in G. Bjork Eydal and T. Rostgaard (eds), Handbook of Child and Family Policy, Cheltenham, UK and Northampton, MA, USA: Edward Elgar Publishing, pp. 84-95.

Bradshaw, J. and Y. Chzhen (2015), 'The outcome of the crisis for pensioners and children', Belgisch Tijdschrift voor Sociale Zekerheid, 1, 37-49.

Bradshaw, J. and O. Movshuk (2019), 'Measures of extreme poverty applied in the European Union', in H. Gaisbauer, G., Schweiger, and C. Sedmak (eds), Absolute Poverty in Europe: Interdisciplinary Perspectives on a Hidden Phenomenon, Bristol: Policy Press, pp. 39-72.

Bradshaw, J., N. Finch, E. Mayhew, V.-M. Ritakallio, and C. Skinner (2006), Child Poverty in Large Families, Bristol: Published for the Joseph Rowntree Foundation by Policy Press. 


\section{Research handbook on the sociology of the family}

Brady, D. (2009), Rich Democracies, Poor People: How Politics Explain Poverty, Oxford: Oxford University Press.

Brady, D., R.M. Finnigan, and S. Hübgen (2017), Rethinking the risks of poverty: A framework for analyzing prevalences and penalties', American Journal of Sociology, 123 (3), 740-86. doi:10.1086/ 693678.

Cantillon, B. (2011), 'The paradox of the social investment state: Growth, employment and poverty in the Lisbon era', Journal of European Social Policy, 21 (5), 432-49. doi:10.1177/0958928711418856.

Cantillon, B., Y. Chzhen, S. Handa, and B. Nolan (eds) (2017), Children of Austerity: Impact of the Great Recession on Child Poverty in Rich Countries, Oxford: Oxford University Press.

Cantillon, B., D. Collado, and N. Van Mechelen (2018), 'The structural nature of the inadequate social floor for single-parent families', in R. Nieuwenhuis and L.C. Maldonado (eds), The Triple Bind of Single-Parent Families: Resources, Employment and Policies to Improve Wellbeing, Bristol: Policy Press, pp. 401-18. doi:10.2307/j.ctt2204rvq.24.

Cantillon, B., T. Goedemé, and J. Hills (eds) (2019), Decent Incomes for All: Improving Policies in Europe, Oxford: Oxford University Press.

Chzhen, Y. and J. Bradshaw (2012), 'Single parents, poverty and policy in the European Union', Journal of European Social Policy, 22 (5), 487-506. doi:10.1177/0958928712456578.

Cooke, L.P. (2018), 'The pathology of patriarchy and family inequalities', in N. Cahn, J. Carbone, L.F. DeRose, and W.B. Wilcox (eds), Unequal Family Lives, Cambridge: Cambridge University Press, pp. 237-60. doi:10.1017/9781108235525.012.

Cowell, F.A. (2011), Measuring Inequality, 3rd edition, Oxford: Oxford University Press.

Daley, A., T. Garner, S. Phipps, and E. Sierminska (2020), 'Differences across place and time in household expenditure patterns: Implications for the estimation of equivalence scales', LIS Working Paper Series, No. 781.

Daly, M. (2011), 'What adult worker model? A critical look at recent social policy reform in Europe from a gender and family perspective', Social Politics: International Studies in Gender, State and Society, 18 (1), 1-23. doi:10.1093/sp/jxr002.

De Lange, M. and J. Dronkers (2018), 'Single parenthood and children's educational performance: Inequality among families and schools', in R. Nieuwenhuis and L.C. Maldonado (eds), The Triple Bind of Single-Parent Families: Resources, Employment and Policies to Improve Well-Being, Bristol: Policy Press, pp. 125-43. doi:10.2307/j.ctt2204rvq.12.

Doctrinal, L. and R. Nieuwenhuis (2019), 'Who closes the gender gap in old-age poverty?', Inequality Matters: LIS Newsletter, No. 11, pp. 8-10. www.lisdatacenter.org/wp-content/uploads/files/nl -2019-11.pdf.

Esser, I. and K.M. Olsen (2018), 'Matched on job qualities? Single and coupled parents in European comparison', in R. Nieuwenhuis and L.C. Maldonado (eds), The Triple Bind of Single-Parent Families: Resources, Employment and Policies to Improve Well-Being, Bristol: Policy Press, pp. 285-310. doi: 10.2307/j.ctt2204rvq.19.

Eurostat (2020), Eurostat Statistics Database, accessed April 2020 at https:/ec.europa.eu/eurostat/data/ database/information.

Fredriksson, D. (2020), 'Moving targets: Target groups of active labour market policies and transitions to employment in Europe: Moving targets', International Journal of Social Welfare, 29 (3). doi:10 $.1111 /$ ijsw.12421.

Gambaro, L., K. Stewart, and J. Waldfogel (2015), An Equal Start? Providing Quality Early Education and Care for Disadvantaged Children, Bristol: Policy Press.

Ghysels, J. and W. Van Lancker (2011), 'The unequal benefits of activation: An analysis of the social distribution of family policy among families with young children', Journal of European Social Policy, 21 (5), 472-85. doi:10.1177/0958928711418853.

Guio, A.-C., D. Gordon, E. Marlier, H. Najera, and M. Pomati (2017), 'Towards an EU measure of child deprivation', Child Indicators Research, 11 (3), 835-60. doi:10.1007/s12187-017-9491-6.

Härkönen, J. (2018), 'Single-mother poverty: How much do educational differences in single motherhood matter?', in R. Nieuwenhuis and L.C. Maldonado (eds), The Triple Bind of Single-Parent Families: Resources, Employment and Policies to Improve Well-Being, Bristol: Policy Press, pp. 31-50. doi:10 $.2307 /$ j.ctt2204rvq.8. 
Härkönen, J., E. Lappalainen, and M. Jalovaara (2016), 'Double disadvantage in a Nordic welfare state: A demographic analysis of the single mother employment gap in Finland, 1987-2011', Stockholm Research Reports in Demography, No. 11.

Hemerijck, A. (ed.) (2017), The Uses of Social Investment, Oxford: Oxford University Press.

Jaehrling, K., T. Kalina, and L. Mesaros (2015), 'A paradox of activation strategies: Why increasing labour market participation among single mothers failed to bring down poverty rates', Social Politics: International Studies in Gender, State and Society, 22 (1), 86-110. doi:10.1093/sp/jxu017.

Jenkins, S.P. (2020), 'Perspectives on poverty in Europe: Following in Tony Atkinson's footsteps', Italian Economic Journal, 6, 129-55. doi:10.1007/s40797-019-00112-0.

Kalleberg, A.L. (2018), Precarious Lives: Job Insecurity and Well-Being in Rich Democracies, Bristol: Polity Press.

Lohmann, H. and E. Crettaz (2018), ‘Explaining cross-country differences in in-work poverty', in H. Lohmann and I. Marx (eds), Handbook on In-Work Poverty, Cheltenham, UK and Northampton, MA, USA: Edward Elgar Publishing, pp. 50-69. doi:10.4337/9781784715632.

Lohmann, H. and I. Marx, I. (eds) (2018), Handbook on In-Work Poverty, Cheltenham, UK and Northampton, MA, USA: Edward Elgar Publishing. doi:10.4337/9781784715632.

Maldonado, L.C. and R. Nieuwenhuis (2015), 'Family policies and single parent poverty in 18 OECD countries, 1978-2008', Community, Work and Family, 18 (4), 395-415. doi:10.1080/13668803.2015 .1080661 .

McLanahan, S. (2004), 'Diverging destinies: How children are faring under the second demographic transition', Demography, 41 (4), 607-27.

Morel, N., B. Palier, and J. Palme (eds) (2012), Towards a Social Investment Welfare State? Ideas, Policies and Challenges, Bristol: Policy Press.

Muller, J.S., N. Hiekel, and A.C. Liefbroer (2020), 'The long-term costs of family trajectories: Women's later-life employment and earnings across Europe', Demography, 57, 1007-34. doi:10 $.1007 / \mathrm{s} 13524-020-00874-8$.

Nelson, K., D. Fredriksson, T. Korpi, W. Korpi, J. Palme. and O. Sjöberg (2020), 'The social policy indicators (SPIN) database', International Journal of Social Welfare, 29 (3), 285-9. doi:10.1111/ijsw .12418 .

Nieuwenhuis, R. and L.C. Maldonado (eds) (2018a), The Triple Bind of Single-Parent Families: Resources, Employment and Policies to Improve Wellbeing, Bristol: Policy Press. doi:10.2307/j .ctt2204rvq.

Nieuwenhuis, R. and L.C. Maldonado (2018b), 'Single-parent families and in-work poverty', in H. Lohmann and I. Marx (eds), Handbook on In-Work Poverty, Cheltenham, UK and Northampton, MA, USA: Edward Elgar Publishing, pp. 171-92. doi:10.4337/9781784715632.

Nieuwenhuis, R., A. Need, and H. Van der Kolk (2012), 'Institutional and demographic explanations of women's employment in 18 OECD countries, 1975-1999', Journal of Marriage and Family, 74 (3), 614-30. doi:10.1111/j.1741-3737.2012.00965.x.

Nieuwenhuis, R., W. Van Lancker, D. Collado, and B. Cantillon (2020), 'Trends in women's employment and poverty rates in OECD countries: A Kitagawa-Blinder-Oaxaca Decomposition', Italian Economic Journal, 6, 37-61. doi:10.1007/s40797-019-00115-x.

OECD (2015), In It Together: Why Less Inequality Benefits All, Paris: OECD. doi:10.1787/ 9789264235120-en.

OECD (2019), OECD Tax-Benefit Web Calculatorm, accessed May 2020 at www.oecd.org/els/soc/tax -benefit-web-calculator.

Pettit, B. and J.L. Hook (2009), Gendered Tradeoffs: Family, Social Policy and Economic Inequality in Twenty-One Countries, New York City: Russell Sage Foundation.

Saraceno, C. (2015), 'A critical look to the social investment approach from a gender perspective', Social Politics: International Studies in Gender, State and Society, 22 (2), 257-69. doi:10.1093/sp/jxv008.

Sen, A.K. (1993), 'Capability and well-being', in M.C. Nussbaum and A.K. Sen (eds), The Quality of Life, Oxford: Clarendon Press.

Smeeding, T.M. (2017), 'Poverty measurement', in D. Brady and L.M. Burton (eds), The Oxford Handbook of the Social Science of Poverty, Oxford: Oxford University Press. doi:10.1093/oxfordhb/ 9780199914050.013.3. 


\section{Research handbook on the sociology of the family}

Sumner, A. (2016), Global Poverty: Deprivation, Distribution and Development since the Cold War, Oxford: Oxford University Press.

Townsend, P. (2010), 'The meaning of poverty', British Journal of Sociology, 61, 85-102. doi:10.1111/ j.1468-4446.2009.01241.x.

Treanor, M. (2018), 'Income poverty, material deprivation and lone parenthood', in R. Nieuwenhuis and L.C. Maldonado (eds), The Triple Bind of Single-Parent Families: Resources, Employment and Policies to Improve Well-Being, Bristol: Policy Press, pp. 81-100. doi:10.2307/j.ctt2204rvq.10.

Van Lancker, W. and J. Vinck (2019), 'The consequences of growing up poor', in B. Greve (ed), International Handbook of Poverty, London: Routledge, pp. 96-106.

Van Mechelen, N. and J. Bradshaw (2013), 'Child benefit packages for working families, 1992-2009', in I. Marx and K. Nelson (eds), Minimum Income Protection in Flux, Houndmills: Palgrave Macmillan, pp. 81-107.

Vandenbroucke, F. and K. Vleminckx (2011), 'Disappointing poverty trends: Is the social investment state to blame?', Journal of European Social Policy, 21 (5), 450-71. doi:10.1177/0958928711418857.

Verbist, G., R. Diris, and F. Vandenbroucke (2020), 'Solidarity between generations in extended families: Old-age income as a way out of child poverty?', European Sociological Review, 36 (2), 317-32. doi:10.1093/esr/jcz052. 